\title{
STABILITAS FISIK DAN KIMIA MINYAK BIJI KETAPANG (Terminalia catappa L.) SELAMA PENYIMPANAN
}

\author{
Delima Saputri, Victoria Yulita Fitriani, Muhammad Amir Masruhim \\ Laboratorium Penelitian dan Pengembangan FARMAKA TROPIS, Fakultas Farmasi, Universitas Mulawarman, \\ Samarinda, Kalimantan Timur \\ e-mail : delima_saputri@ymail.com
}

\begin{abstract}
Ketapang (Terminalia catappa L.) is each one potentialy to producting of nabati oil. The research is purposes to determine effect of storage period on room and extreme temperature of ketapang seeds oil's physical and chemical stability. Ketapang seeds oil was getted from ketapang seeds extraction by n-hexana with soxhletasi method. Ketapang seeds oil stability evaluation on room temperature $27-30{ }^{\circ} \mathrm{C}$ as long as 50 days and extreme temperature 65 ${ }^{\circ} \mathrm{C}$ as long as 10 days. Physical stability that color, aroma, and flavor use organolepticly, $\mathrm{pH}$ use pH-meter, density use piknometer, and viscosity use Oswald viscometer. Chemical stability that acid value, peroxide value, and soap value by titration method, and amount of tocopherol compound by spectrometry method. The result data was analyzed with linier regretion. The analyzed result of aroma, flavor, $\mathrm{pH}$, density, soap value, and tocopherol compound showed descend linier, viscosity, acid value, and peroxide value showed ascend linier, and color of ketapang seeds oil is stabil as long as storage on room and extreme temperature. Storage period on extreme temperature more significant than room temperature to effect evaluation result of ketapang seeds oil's physical and chemical parameters.
\end{abstract}

Key Words: Terminalia catappa L., Storage Period, Physical and Chemical Stability.

\begin{abstract}
Abstrak
Ketapang (Terminalia catappa L.) merupakan salah satu tumbuhan yang berpotensi sebagai penghasil minyak nabati. Penelitian ini bertujuan untuk mengetahui pengaruh lama penyimpanan pada suhu ruang dan ekstrim terhadap stabilitas fisik dan kimia minyak biji ketapang. Minyak biji ketapang diperoleh dari ekstraksi biji ketapang dengan pelarut $n$ heksana menggunakan metode soxhletasi. Penentuan stabilitas fisik minyak meliputi warna, bau, dan rasa, $\mathrm{pH}$, bobot jenis, dan viskositas. Penentuan stabilitas kimia meliputi penentuan angka asam, angka peroksida, dan angka penyabunan, serta kandungan tokoferol. Hasil pengujian dianalisis menggunakan regresi linier. Berdasarkan hasil analisis, disimpulkan bahwa pada parameter bau, rasa, $\mathrm{pH}$, bobot jenis, angka penyabunan, dan kandungan tokoferol menunjukkan hubungan linier dengan kecenderungan turun, pengujian terhadap parameter viskositas, angka asam, dan angka peroksida menunjukkan hubungan linier dengan kecenderungan naik, sedangkan parameter warna minyak biji ketapang cenderung stabil selama penyimpanan pada suhu ruang maupun suhu ekstrim. Lama penyimpanan pada suhu ekstrim lebih signifikan mempengaruhi hasil pengujian pada parameter fisik dan kimia minyak biji ketapang dibandingkan pada suhu ruang.
\end{abstract}

Kata Kunci : Terminalia catappa L., Lama Penyimpanan, Stabilitas Fisik dan Kimia. 


\section{PENDAHULUAN}

Tumbuhan ketapang merupakan salah satu tumbuhan yang berpotensi sebagai penghasil minyak nabati. Minyak nabati digunakan sebagai pelarut/pembawa injeksi di bidang Farmasi, karena dapat mensolubilisasi obat yang sangat lipofilik dan jika diberikan secara intramuskular pada massa otot akan menghasilkan depot untuk menunda/memperpanjang pelepasan obat.

Telah banyak penelitian yang dilakukan pada minyak dari biji ketapang. Balogun dan Fetuga (1985) menyebutkan bahwa biji Terminalia catappa L. mengandung minyak sebesar 40,15\%, sehingga minyak biji ketapang memiliki prospek untuk dijadikan suatu pilihan baru dalam industri minyak nabati. Minyak biji ketapang berpeluang untuk digunakan sebagai minyak pangan dan bahan baku industri sabun, lilin dan minyak pelumas.

Hasil uji karakteristik terhadap biodiesel yang disintesis dari minyak biji ketapang (Terminalia catappa L.) yang telah dilakukan Suwarso et al. (2007) menyimpulkan bahwa biodiesel dari minyak biji ketapang (Terminalia catappa L.) mendekati karakteristik minyak diesel no. 2-D, yang biasa digunakan pada mesinmesin industri dan kendaraan berat.

Analisis biji ketapang (Terminalia catappa L.) sebagai suatu alternatif sumber minyak nabati yang telah dilakukan oleh Miladiah dan Subagus (2008) menyimpulkan bahwa minyak biji ketapang berpeluang untuk sebagai alternatif pengganti minyak kelapa sawit dan minyak zaitun, berdasarkan kemiripan sifat fisika kimia dan kandungan asam lemaknya.
Tumbuhan dan lingkungan tempat tumbuh merupakan suatu kesatuan yang tidak terpisahkan karena untuk dapat berkembang dengan baik, tumbuhan membutuhkan keadaan lingkungan yang optimum untuk mengekspresikan program genetiknya secara penuh. Adanya perbedaan kondisi lingkungan tempat tumbuh dapat menyebabkan perbedaan kandungan dan stabilitas minyak biji ketapang (MBK). Oleh karena itu, penelitian tentang stabilitas minyak dari biji ketapang yang tumbuh di Kalimantan Timur masih perlu dilakukan untuk menambah data ilmiah tentang biji ketapang (Terminalia catappa L.).

\section{METODE PENELITIAN}

\section{Bahan}

Bahan yang digunakan adalah biji ketapang diperoleh di Universitas Mulawarman Samarinda Kalimantan Timur, $n$-heksana (Jong Java), kertas saring, $\mathrm{Na}_{2} \mathrm{SO}_{4}$ anhidrid (Merck), air suling, asam asetat (Merck), kloroform (Brotaco), KI (Merck), amilum (Merck), indikator phenolphthalein (Merck), Etanol 95\% (Jong Java), $\mathrm{HCl}$ (Sigma), KOH dalam Alkohol, $\mathrm{Na}_{2} \mathrm{~S}_{2} \mathrm{O}_{3} .5 \mathrm{H}_{2} \mathrm{O}$ (Merck), $\mathrm{K}_{2} \mathrm{Cr}_{2} \mathrm{O}_{7}$ (Merck), $\mathrm{H}_{2} \mathrm{C}_{2} \mathrm{O}_{4}$ (Brotaco), $\mathrm{KOH}$.

\begin{abstract}
Alat
Alat yang dipergunakan adalah seperangkat alat gelas (Pyrex), alat soxhletasi (Labentech), alat evaporasi (Eyela), timbangan analitik (Mettler Toledo), alat sentrifuse (Gemmy Industrial), oven (Yenaco), alat titrasi (Pyrex).
\end{abstract}




\section{Prosedur Penelitian}

\section{Pembuatan MBK (Minyak Biji Ketapang)}

Biji ketapang dibersihkan, kemudian dikeringanginkan di udara terbuka dalam ruangan, dihaluskan menggunakan blender, serbuk halus dibungkus dengan kertas saring dan dimasukkan dalam tabung soxhlet untuk diekstraksi dengan $n$-heksana pada suhu $40{ }^{\circ} \mathrm{C}$ selama 7 jam. Hasil ekstraksi dirotary evaporator untuk memisahkan dengan pelarut. Pemurnian MBK terdiri atas tahap pemucatan atau adsorbing agent dengan penambaahan $\mathrm{Na}_{2} \mathrm{SO}_{4}$ anhidrid $0,1 \mathrm{~g}$ tiap $10 \mathrm{~mL}$ minyak, pengendapan (settling) dengan sentrifugasi dan pemisahan gumi (degumming) dengan penyaringan.

\section{Uji stabilitas fisik dan kimia MBK}

Stabilitas fisik dan kimia MBK diuji pada dua kondisi suhu dan lama penyimpanan yang berbeda, yaitu suhu ekstrim $65{ }^{\circ} \mathrm{C}$ selama 10 hari dan suhu ruang $\left(27-30{ }^{\circ} \mathrm{C}\right)$ selama 50 hari. Stabilitas fisik dan kimia yang diuji meliputi :

a. Uji stabilitas fisik MBK:

1) Uji organoleptik

Uji organoleptik meliputi pengujian stabilitas warna, bau, dan rasa, menggunakan 3 orang sebagai panelis.

2) $\mathrm{Uji} \mathrm{pH}$

Pengujian $\mathrm{pH}$ menggunakan alat $\mathrm{pH}$ meter.

3) Uji bobot jenis

Prosedur pengujian bobot jenis menurut SNI 06-4085-1996.
4) Uji viskositas

Pengujian viskositas menggunakan viskometer kapiler atau viskometer Oswald.

b. Uji stabilitas kimia MBK:

1) Uji angka asam

Penentuan angka asam meliputi langkahlangkah pada AOAC, 1990.

2) Uji angka peroksida

Penentuan besarnya angka peroksida dilakukan dengan titrasi iodometri, melalui tahap-tahap pada AOAC, 1990.

3) Uji angka penyabunan

Penentuan angka penyabunan meliputi langkah-langkah titrasi menurut Winarno (1984).

4) Kandungan tokoferol

Prosedur penentuan kandungan tokoferol dilakukan dengan spektrofotometri menurut Harborne (1987).

\section{HASIL DAN PEMBAHASAN}

Minyak biji ketapang (MBK) adalah minyak yang diperoleh dari ekstraksi biji ketapang. Penelitian ini bertujuan untuk mengetahui pengaruh lama penyimpanan pada suhu ruang dan suhu ekstrim terhadap stabilitas fisik dan kimia MBK.

Pengujian stabilitas MBK pada suhu penyimpanan $65{ }^{\circ} \mathrm{C}$ selama 10 hari, karena setiap produk pasti mengalami proses pendistribusian yang panjang dari tempat produksi hingga sampai ke tangan konsumen. Schmitt (1996) menjelaskan bahwa suhu $65{ }^{\circ} \mathrm{C}$ merupakan rata-rata 
suhu di dalam media transportasi seperti truk kontainer yang mendistribusikan produk karena selama perjalanan, suhu produk akan meningkat seiring dengan perubahan suhu di luar media transportasi. Sedangkan, 10 hari digunakan sebagai data yang representatif karena Nurhadi (2012) menjelaskan bahwa 5 hari saja diasumsikan sudah cukup untuk menggambarkan keadaan lama perjalanan pendistribusian suatu produk. Pengujian stabilitas minyak biji ketapang pada suhu penyimpanan 27-30 ${ }^{\circ} \mathrm{C}$ selama 50 hari mengindikasikan kondisi saat produk disimpan di toko atau di ruangan.

Parameter fisik yang diujikan meliputi organoleptik, $\mathrm{pH}$, bobot jenis, dan viskositas. Parameter fisik dipilih karena parameter-parameter tersebut dapat menunjukkan stabilitas minyak berdasarkan sifat fisik minyak yang diujikan.

Sedangkan, parameter kimia yang diujikan meliputi angka asam, angka peroksida, angka penyabunan, dan kandungan tokoferol. Pengujian pada parameter kimia minyak biji ketapang berfungsi untuk menjamin keamanan dan kelayakan minyak ketika dipasarkan di kalangan masyarakat berdasarkan sifat kimianya.

\section{Uji Organoleptik}

Uji organoleptik merupakan uji menggunakan bantuan organ tubuh seperti mata, hidung dan lidah. Mata dalam pengujian ini digunakan untuk menentukan warna bahan, kehadiran bahan asing, dan tingkat kerusakan, hidung digunakan untuk menentukan bau, sedangkan lidah digunakan untuk menentukan rasa dari bahan yang diujikan.
Pada pengujian organoleptik yang meliputi warna, bau, dan rasa, digunakan panelis yang bertugas untuk menilai sifat dan mutu minyak berdasarkan kesan obyektif pada penilaian dengan indra. Obyektif menunjukkan derajat persamaan persepsi antar panelis.

Hasil pengujian warna oleh panelis mengacu pada Gambar 1. Berdasarkan hasil pengujian, warna minyak biji ketapang yang dihasilkan adalah kuning bening. Warna tersebut tidak berubah meskipun terdapat perlakuan suhu ekstrim $\left(65^{\circ} \mathrm{C}\right)$, maupun waktu yang cukup lama yaitu 50 hari pada suhu ruang. Hal ini menunjukkan bahwa warna minyak yang dihasilkan masih tetap stabil berwarna kuning bening.

Warna stabil pada minyak biji ketapang disebabkan oleh hilangnya pigmen penyebab warna minyak akibat perlakuan pada pemurnian minyak. Berbagai macam pigmen seperti karotenoid, klorofil, dan tokoferol terdapat dalam minyak menyebabkan warna tidak stabil dan mudah teroksidasi, menimbulkan warna coklat pada minyak. Penambahan adsorben agent dan sentrifugasi dapat mengendapkan pigmen penyebab warna tidak stabil sehingga dengan penyaringan dapat menghilangkan pigmen tersebut dari minyak. Persyaratan minyak untuk injeksi berdasarkan FI III adalah harus jernih untuk menunjukkan tingkat kemurnian yang tinggi.

Hasil pengujian bau oleh panelis berdasarkan instruksi untuk menyatakan kesan sensorik tiap melakukan pengujian dimana (4) sangat menyengat, menyengat, (2) kurang menyengat, dan (1) tidak menyengat. 


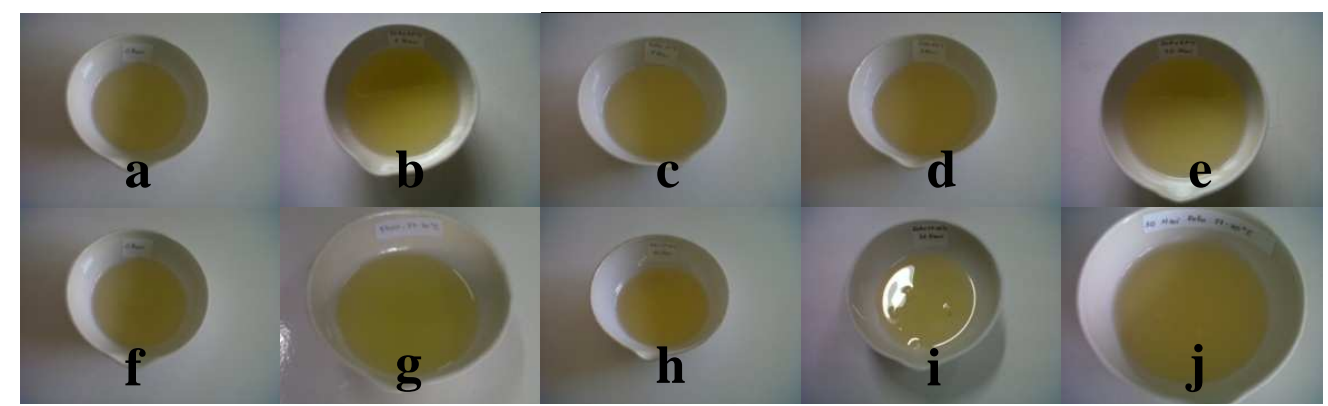

Gambar 1. Hasil pengujian warna minyak biji ketapang pada suhu penyimpanan $65^{\circ} \mathrm{C}$ selama: (a) 0 hari; (b) 1 hari; (c) 4 hari; (d) 7 hari; (e) 10 hari; pada suhu penyimpanan $27-30{ }^{\circ} \mathrm{C}$ selama : $(f) 0$ hari; $(\mathrm{g})$ 10 hari; (h) 20 hari; (i) 30 hari; (j) 50 hari.
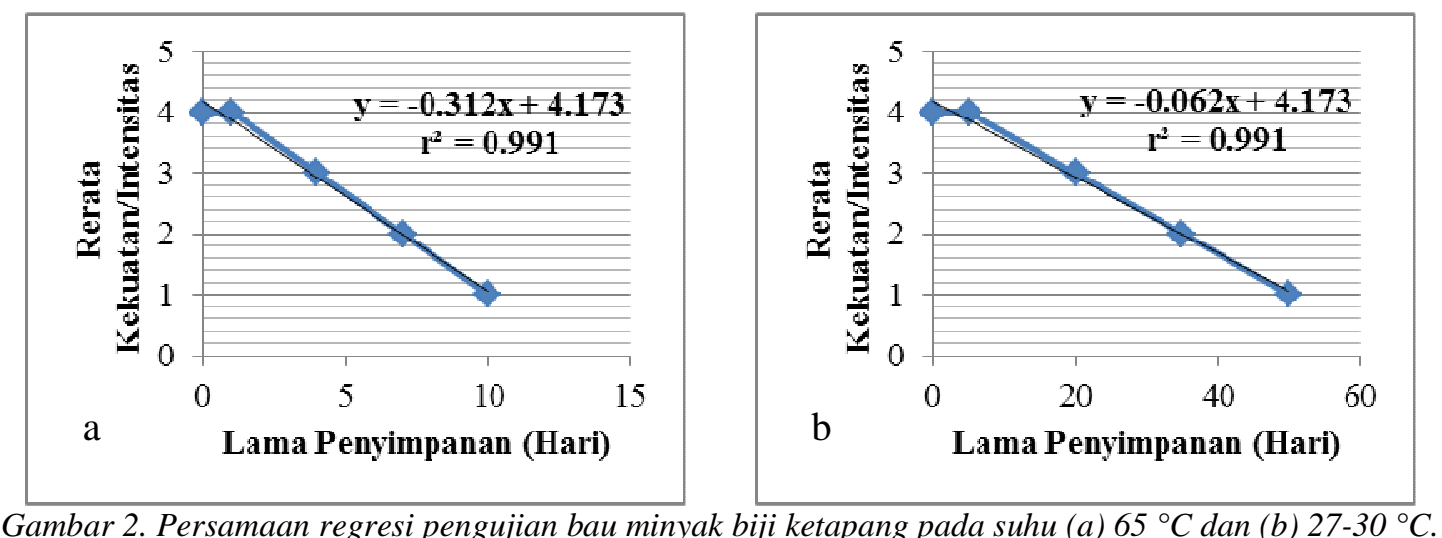

Berdasarkan persamaan regresi pada Gambar 2 dapat dilihat bahwa semakin lama penyimpanan, minyak biji ketapang yang diujikan mempunyai kecenderungan mengalami penurunan kekuatan bau.

Melalui persamaan regresi juga memperlihatkan hubungan linier dengan kencenderungan turun (slope negatif) pada kekuatan bau sebesar $-0,312$ pada suhu penyimpanan $65{ }^{\circ} \mathrm{C}$ dan $-0,062$ pada suhu penyimpanan $27-30{ }^{\circ} \mathrm{C}$. Berdasarkan nilai slope tersebut, lama penyimpanan pada suhu $65{ }^{\circ} \mathrm{C}$ lebih signifikan mempengaruhi penurunan kekuatan bau dibandingkan lama penyimpanan pada suhu $27-30{ }^{\circ} \mathrm{C}$.

Harga $r$ tabel terhadap waktu pengujian adalah 0,878 untuk taraf kesalahan 5\% dan 0,959 untuk taraf kesalahan $1 \%$. Koefisien korelasi $r=-0,995$ pada kedua kondisi

penyimpanan lebih kecil dari $r$ tabel $1 \%$ dan 5\%, maka dapat disimpulkan bahwa lama penyimpanan pada kedua kondisi memiliki hubungan sempurna negatif namun tidak signifikan terhadap penurunan kekuatan bau.

Koefisien determinasi $r^{2}=0,991$, hal ini berarti penurunan kekuatan bau 99,1\% ditentukan oleh lama penyimpanan pada kedua kondisi, sedangkan sisanya $0,9 \%$ ditentukan oleh faktor lain.

Bau dapat tercium bila ada senyawa volatile yang mudah menguap dan tertangkap indra penciuman. Penurunan kekuatan bau diakibatkan oleh faktor peningkatan suhu yang mungkin terjadi selama penyimpanan. Peningkatan suhu penyimpanan dapat menyebabkan penguapan senyawa volatile sehingga minyak mengalami penghilangan bau. 
Tidak berbau tengik/asing merupakan salah satu persyaratan minyak untuk injeksi.

Hasil pengujian rasa oleh panelis berdasarkan instruksi untuk menyatakan kesan sensorik tiap melakukan pencicipan dimana (2) sangat pahit, dan (1) pahit.

Berdasarkan persamaan regresi pada Gambar 3 dapat dilihat bahwa semakin lama penyimpanan, minyak biji ketapang yang diujikan mempunyai kecenderungan mengalami penurunan kekuatan rasa.

Melalui persamaan regresi juga memperlihatkan hubungan linier dengan kencenderungan turun (slope negatif) pada kekuatan rasa sebesar $-0,112$ pada suhu penyimpanan $65^{\circ} \mathrm{C}$ dan $-0,022$ pada suhu penyimpanan $27-30{ }^{\circ} \mathrm{C}$. Berdasarkan nilai slope tersebut, lama penyimpanan pada suhu $65{ }^{\circ} \mathrm{C}$ lebih signifikan mempengaruhi penurunan kekuatan rasa dibandingkan lama penyimpanan pada suhu $27-30{ }^{\circ} \mathrm{C}$.
Koefisien korelasi $r=-0,855$ pada kedua kondisi penyimpanan lebih kecil dari $\mathrm{r}$ tabel $1 \%$ dan 5\%, maka dapat disimpulkan bahwa lama penyimpanan pada kedua kondisi memiliki hubungan sempurna negatif namun tidak signifikan terhadap penurunan kekuatan rasa.

Koefisien determinasi $r^{2}=0,732$, hal ini berarti penurunan kekuatan bau hanya $73,2 \%$ ditentukan oleh lama penyimpanan, sedangkan sisanya $26,8 \%$ ditentukan oleh faktor lain.

Rasa pahit pada minyak biji ketapang diduga berasal dari kandungan senyawasenyawa yang bersifat basa. Penurunan kekuatan rasa disebabkan oleh proses kerusakan minyak yang menghasilkan asam lemak bebas yang dapat mengendapkan basa tersebut. Semakin lama penyimpanan, asam lemak bebas yang terbentuk semakin besar sehingga kandungan basa semakin menurun menyebabkan penurunan kekuatan rasa.
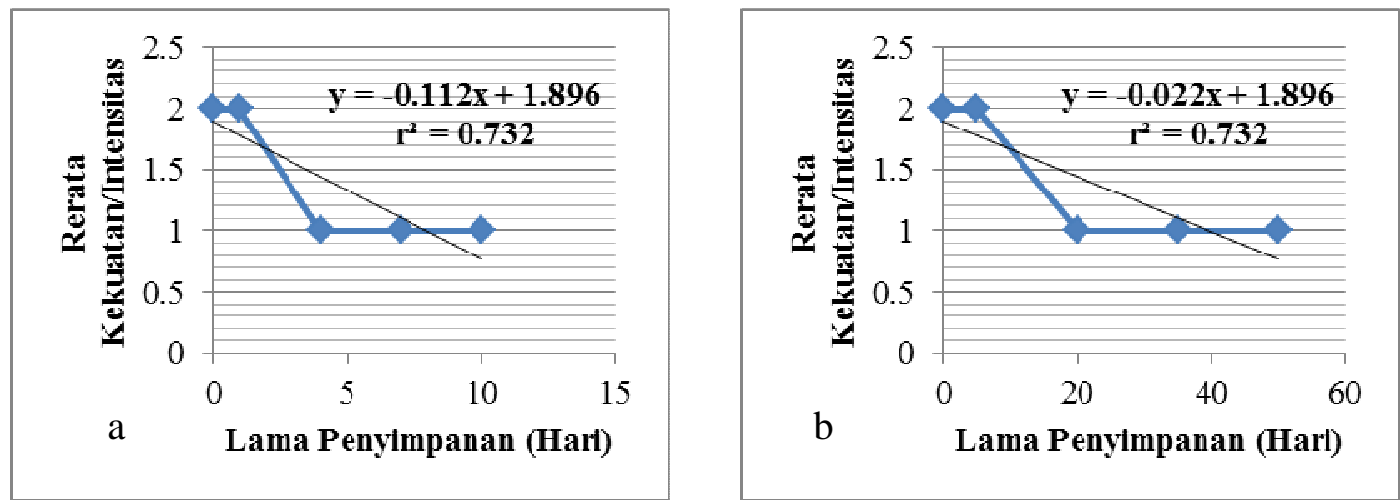

Gambar 3. Persamaan regresi pengujian rasa minyak biji ketapang suhu (a) $65^{\circ} \mathrm{C}$ dan (b) $27-30{ }^{\circ} \mathrm{C}$.

\section{pH}

$\mathrm{pH}$ menyatakan derajat keasaman suatu sampel karena merupakan negatif logaritma dasar 10 dari konsentrasi ion $\mathrm{H}^{+}$. Berdasarkan persamaan regresi pada Gambar 4 dapat dilihat bahwa semakin lama penyimpanan, minyak biji ketapang yang diujikan mempunyai kecenderungan mengalami penurunan $\mathrm{pH} . \mathrm{pH}$ awal minyak biji ketapang sebelum perlakuan, 0 hari yaitu 5,62, kemudian mengalami penurunan setelah perlakuan yaitu 4,74 pada suhu $65^{\circ} \mathrm{C}$ selama 10 hari dan 4,63 pada suhu 27-30 ${ }^{\circ} \mathrm{C}$ selama 50 hari. Penurunan $\mathrm{pH}$ tersebut menunjukkan 
ketidakstabilan $\mathrm{pH}$ minyak biji ketapang selama penyimpanan, namun tidak signifikan.

Melalui persamaan regresi juga memperlihatkan hubungan linier dengan kecenderungan turun (slope negatif) pada pH sebesar -0,072 pada suhu penyimpanan $65^{\circ} \mathrm{C}$ dan $-0,013$ pada suhu penyimpanan 27-30 ${ }^{\circ} \mathrm{C}$. Berdasarkan nilai slope tersebut, lama penyimpanan pada suhu $65{ }^{\circ} \mathrm{C}$ lebih signifikan mempengaruhi penurunan $\mathrm{pH}$ dibandingkan lama penyimpanan pada suhu $27-30{ }^{\circ} \mathrm{C}$.

Koefisien korelasi $r=-0,857$ pada suhu penyimpanan $65^{\circ} \mathrm{C}$ dan $-0,713$ pada suhu penyimpanan $27-30{ }^{\circ} \mathrm{C}, r$ hitung pada kedua kondisi penyimpanan tersebut lebih kecil dari $r$ tabel $1 \%$ dan 5\%, maka dapat disimpulkan bahwa lama penyimpanan pada kedua kondisi memiliki hubungan sempurna negatif namun tidak signifikan terhadap penurunan $\mathrm{pH}$.

Koefisien determinasi $r^{2}=0,732$, hal ini berarti bahwa penurunan $\mathrm{pH}$ hanya $73,2 \%$ ditentukan oleh lama penyimpanan pada suhu $65{ }^{\circ} \mathrm{C}$, sedangkan $r^{2}=0,509$, hal ini berarti bahwa penurunan $\mathrm{pH}$ hanya $50,9 \%$ ditentukan oleh lama penyimpanan pada suhu $27-30{ }^{\circ} \mathrm{C}$.

Penyimpanan pada suhu ekstrim dan waktu yang cukup lama dapat menyebabkan terjadinya hidrolisis asam lemak membentuk asam lemak bebas. Semakin besar asam lemak bebas yang terbentuk maka $\mathrm{pH}$ akan semakin menurun. Minyak untuk injeksi harus bersifat netral secara fisiologis agar dapat diterima tubuh dengan baik yaitu sekitar 7,4.

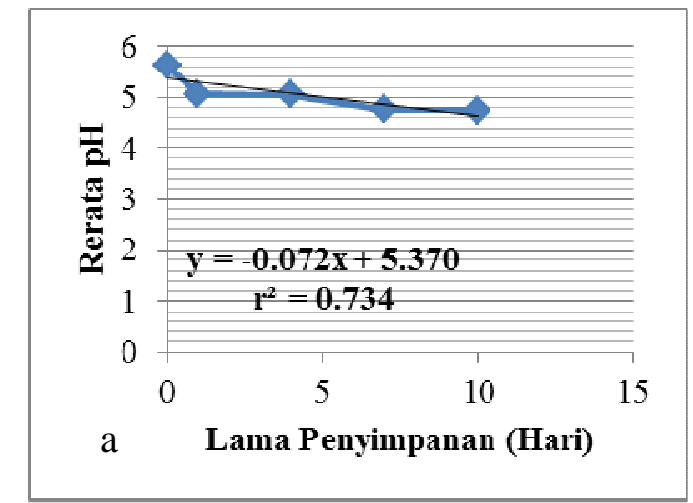

Gambar 4. Persamaan regresi pengujian pH minyak biji ketapang pada suhu (a) $65^{\circ} \mathrm{C}$ dan (b) $27-30^{\circ} \mathrm{C}$.

\section{Bobot Jenis}

Bobot jenis adalah perbandingan berat dari suatu volume contoh dengan berat air pada volume dan suhu pengukuran yang sama. Dari persamaan regresi pada Gambar 5 dapat dilihat bahwa semakin lama penyimpanan, minyak biji ketapang yang diujikan mempunyai kecenderungan mengalami penurunan bobot jenis. Berdasarkan hasil penelitian sebelumnya, minyak biji ketapang memiliki bobot jenis $0,8977 \mathrm{~g} / \mathrm{mL}$, sedangkan bobot jenis awal minyak biji ketapang sebelum perlakuan, 0 hari yaitu 0,895 gram $/ \mathrm{mL}$, kemudian mengalami penurunan setelah perlakuan yaitu $0,78 \mathrm{~g} / \mathrm{mL}$ pada suhu $65{ }^{\circ} \mathrm{C}$ selama 10 hari dan $0,76 \mathrm{~g} / \mathrm{mL}$ pada suhu $27-30{ }^{\circ} \mathrm{C}$ selama 50 hari. Penurunan bobot jenis tersebut menunjukkan ketidakstabilan minyak biji ketapang yang signifikan selama penyimpanan. 
Melalui persamaan regresi juga memperlihatkan hubungan linier dengan kecenderungan turun (slope negatif) pada bobot jenis sebesar -0,012 pada suhu penyimpanan $65^{\circ} \mathrm{C}$ dan $-0,002$ pada suhu penyimpanan $27-30{ }^{\circ} \mathrm{C}$. Berdasarkan nilai slope tersebut, lama penyimpanan pada suhu $65^{\circ} \mathrm{C}$ lebih signifikan mempengaruhi penurunan bobot jenis dibandingkan lama penyimpanan pada suhu $27-30{ }^{\circ} \mathrm{C}$.

Koefisien korelasi $r=-0,942$ pada suhu penyimpanan $65^{\circ} \mathrm{C}$ dan $-0,972$ pada suhu penyimpanan 27-30 ${ }^{\circ} \mathrm{C}, r$ hitung pada kedua kondisi penyimpanan tersebut lebih kecil dari $r$ tabel 1\% dan 5\%, maka dapat disimpulkan bahwa lama penyimpanan pada kedua kondisi memiliki hubungan sempurna negatif namun tidak signifikan terhadap penurunan bobot jenis.

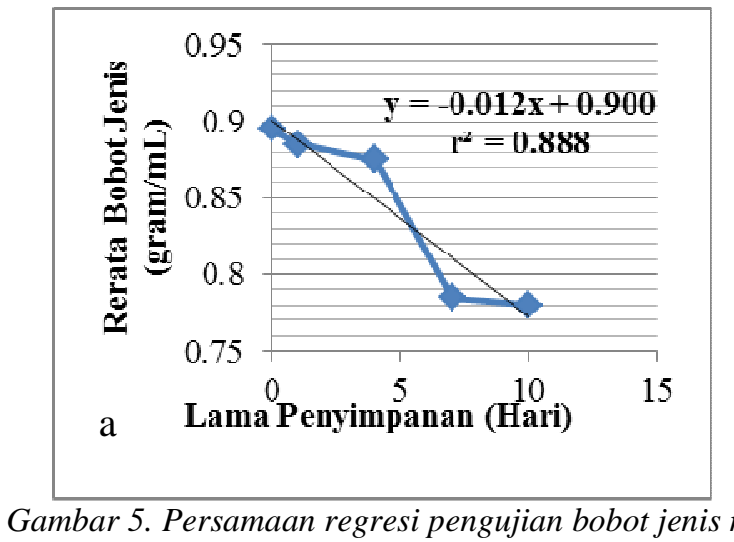

\section{Viskositas}

Viskositas menyatakan tahanan dari suatu cairan untuk mengalir. Berdasarkan persamaan regresi pada Gambar 6 dapat dilihat bahwa semakin lama penyimpanan, minyak biji ketapang yang diujikan mempunyai kecenderungan mengalami peningkatan viskositas. Viskositas awal minyak biji ketapang sebelum perlakuan, 0 hari yaitu $11,74 \mathrm{cP}$, kemudian mengalami
Koefisien determinasi $r^{2}=0,888$, hal ini berarti penurunan bobot jenis $88,8 \%$ ditentukan oleh lama penyimpanan pada suhu penyimpanan $65{ }^{\circ} \mathrm{C}$, sedangkan $r^{2}=$ 0,945 , hal ini berarti penurunan bobot jenis $94,5 \%$ ditentukan oleh lama penyimpanan pada suhu penyimpanan 27 $30{ }^{\circ} \mathrm{C}$.

Lama penyimpanan menyebabkan bobot jenis semakin menurun, hal ini dipengaruhi oleh penurunan derajat ketidakjenuhan minyak. Minyak biji ketapang, tinggi akan asam lemak tidak jenuh yaitu 38,72\% asam oleat. Asam lemak tidak jenuh ini bersifat mudah terurai sehingga kerusakan minyak dapat dilihat dari penurunan berat molekul minyak yang mengindikasikan peningkatan penguraian asam lemak tidak jenuh tersebut.

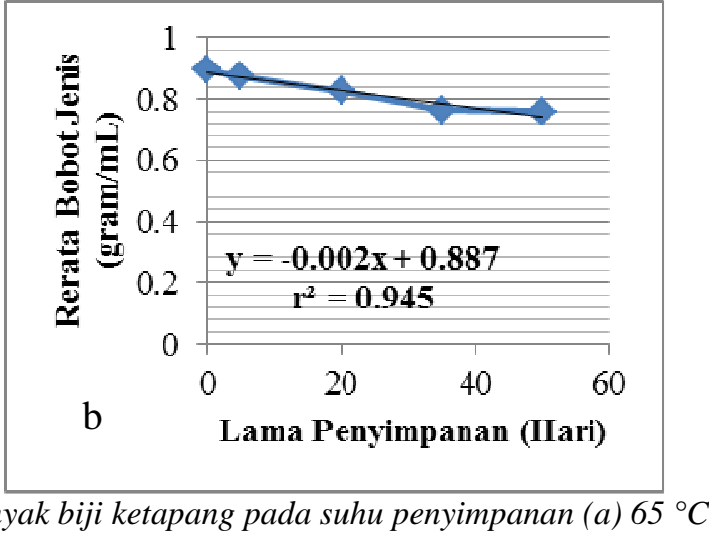
dan (b) $27-30{ }^{\circ} \mathrm{C}$.

peningkatan setelah perlakuan yaitu 53,23 cP pada suhu $65^{\circ} \mathrm{C}$ selama 10 hari dan 54,08 cP pada suhu $27-30{ }^{\circ} \mathrm{C}$ selama 50 hari. Peningkatan viskositas tersebut menunjukkan ketidakstabilan minyak biji ketapang selama penyimpanan, namun tidak signifikan.

Melalui persamaan regresi juga memperlihatkan hubungan linier dengan kecenderungan naik (slope positif) pada 
viskositas sebesar 2,843 pada suhu penyimpanan $65{ }^{\circ} \mathrm{C}$ dan 0,661 pada suhu penyimpanan $27-30{ }^{\circ} \mathrm{C}$. Berdasarkan nilai slope tersebut, lama penyimpanan pada suhu $65^{\circ} \mathrm{C}$ lebih signifikan mempengaruhi peningkatan viskositas dibandingkan lama penyimpanan pada suhu $27-30{ }^{\circ} \mathrm{C}$.

Koefisien korelasi $r=0,73$ pada suhu penyimpanan $65^{\circ} \mathrm{C}$ dan 0,799 pada suhu penyimpanan $27-30{ }^{\circ} \mathrm{C}, r$ hitung pada kedua kondisi penyimpanan tersebut lebih kecil dari $r$ tabel 1\% dan 5\%, maka dapat disimpulkan bahwa lama penyimpanan pada kedua kondisi memiliki hubungan sempurna positif namun tidak signifikan terhadap peningkatan viskositas.

Koefisien determinasi $r^{2}=0,533$, hal ini berarti peningkatan viskositas hanya
53,3\% ditentukan oleh lama penyimpanan pada suhu penyimpanan $65^{\circ} \mathrm{C}$, sedangkan $r^{2}=0,639$, hal ini berarti peningkatan viskositas hanya $63,9 \%$ ditentukan oleh lama penyimpanan pada suhu penyimpanan $27-30{ }^{\circ} \mathrm{C}$.

Peningkatan viskositas minyak biji ketapang selama penyimpanan merupakan salah satu indikasi dari peningkatan kerusakan minyak. Minyak yang mengalami peningkatan viskositas disebabkan oleh terbentuknya senyawa polimer di dalam minyak sehingga meningkatkan kerapatan antar partikel dalam minyak menyebabkan tahanan untuk mengalir semakin besar sehingga waktu alir semakin lama dan viskositas semakin meningkat.

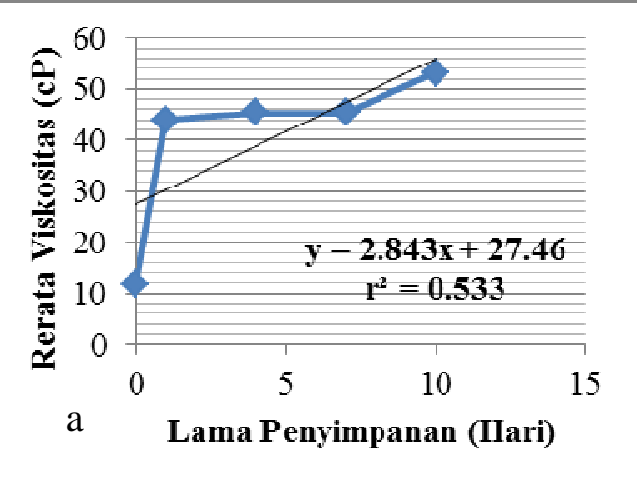

Gambar 6. Persamaan regresi pengujian viskositas mi

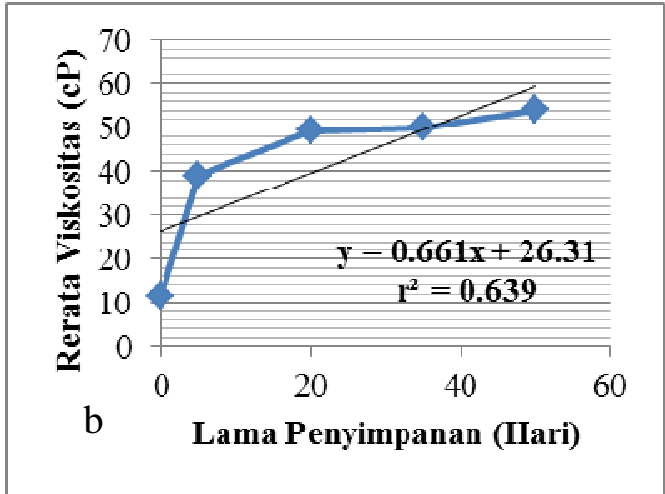

(b) $27-30{ }^{\circ} \mathrm{C}$.

4,7-6 mg $\mathrm{KOH} /$ gram minyak, sedangkan angka asam awal minyak biji ketapang sebelum perlakuan, 0 hari yaitu $1,44 \mathrm{mg}$ $\mathrm{KOH} /$ gram minyak, kemudian mengalami peningkatan setelah perlakuan yaitu 8,93 mg KOH/gram minyak pada suhu $65{ }^{\circ} \mathrm{C}$ selama 10 hari dan $7,58 \mathrm{mg} \mathrm{KOH} / \mathrm{gram}$ minyak pada suhu $27-30{ }^{\circ} \mathrm{C}$ selama 50 hari. Peningkatan angka asam tersebut menunjukkan ketidakstabilan minyak biji ketapang yang signifikan selama penyimpanan. 


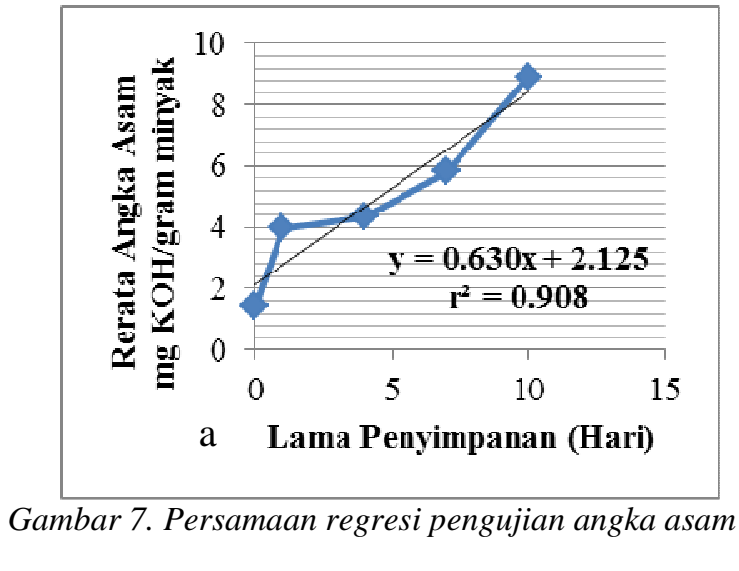

Melalui persamaan regresi juga memperlihatkan hubungan linier dengan kecenderungan naik (slope positif) pada pengujian angka asam sebesar 0,630 pada suhu penyimpanan $65^{\circ} \mathrm{C}$ dan 0,104 pada suhu penyimpanan $27-30{ }^{\circ} \mathrm{C}$. Berdasarkan nilai slope tersebut, lama penyimpanan pada suhu $65{ }^{\circ} \mathrm{C}$ lebih signifikan mempengaruhi peningkatan angka asam dibandingkan lama penyimpanan pada suhu $27-30{ }^{\circ} \mathrm{C}$.

Koefisien korelasi $r=0,953$ pada suhu penyimpanan $65^{\circ} \mathrm{C}$ dan 0,927 pada suhu penyimpanan $27-30{ }^{\circ} \mathrm{C}, \quad r$ hitung pada kedua kondisi penyimpanan tersebut lebih besar dari $r$ tabel 5\% tetapi lebih kecil $r$ tabel $1 \%$, maka dapat disimpulkan bahwa lama penyimpanan pada kedua kondisi memiliki hubungan sempurna positif dan signifikan terhadap peningkatan angka asam.

Koefisien determinasi $r^{2}=0,908$, hal ini berarti peningkatan angka asam 90,8\% ditentukan oleh lama penyimpanan pada suhu $65{ }^{\circ} \mathrm{C}$, sedangkan $r^{2}=0,86$, hal ini berarti peningkatan angka asam $86 \%$ ditentukan oleh lama penyimpanan pada suhu penyimpanan $27-30{ }^{\circ} \mathrm{C}$.

Peningkatan angka asam disebabkan oleh meningkatnya asam lemak bebas yang

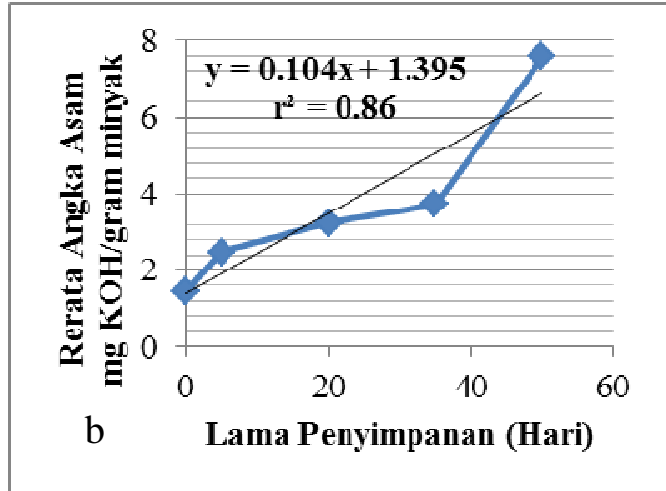

minyak biji ketapang pada suhu penyimpanan (a) $65^{\circ} \mathrm{C}$ dan (b) $27-30^{\circ} \mathrm{C}$.

terdapat di dalam minyak biji ketapang, akibat oksidasi dan pemecahan ikatan rangkap pada asam lemak tidak jenuhnya. Semakin tinggi angka asam menunjukkan semakin rendah kualitas minyak yang diujikan. Persyaratan angka asam minyak untuk injeksi adalah 0,2-0,9 $\mathrm{mg}$ $\mathrm{KOH} /$ gram minyak.

\section{Angka Peroksida}

Angka peroksida adalah miliequivalen dari peroksida dalam 1000 gram minyak biji ketapang. Berdasarkan persamaan regresi pada Gambar 8 dapat dilihat bahwa semakin lama penyimpanan, minyak biji ketapang yang diujikan mempunyai kecenderungan mengalami peningkatan angka peroksida. Berdasarkan hasil penelitian sebelumnya, minyak biji ketapang memiliki angka peroksida 3,20 $\mathrm{mEq} / \mathrm{kg}$ minyak, sedangkan angka peroksida awal minyak biji ketapang sebelum perlakuan, 0 hari yaitu 0,45 $\mathrm{mEq} / \mathrm{kg}$ minyak, kemudian mengalami peningkatan setelah perlakuan yaitu 6,53 $\mathrm{mEq} / \mathrm{kg}$ minyak pada suhu $65{ }^{\circ} \mathrm{C}$ selama 10 hari dan $6,18 \mathrm{mEq} / \mathrm{kg}$ minyak pada suhu 27-30 ${ }^{\circ} \mathrm{C}$ selama 50 hari. Peningkatan angka peroksida tersebut menunjukkan ketidakstabilan minyak biji ketapang yang sangat signifikan selama penyimpanan. 

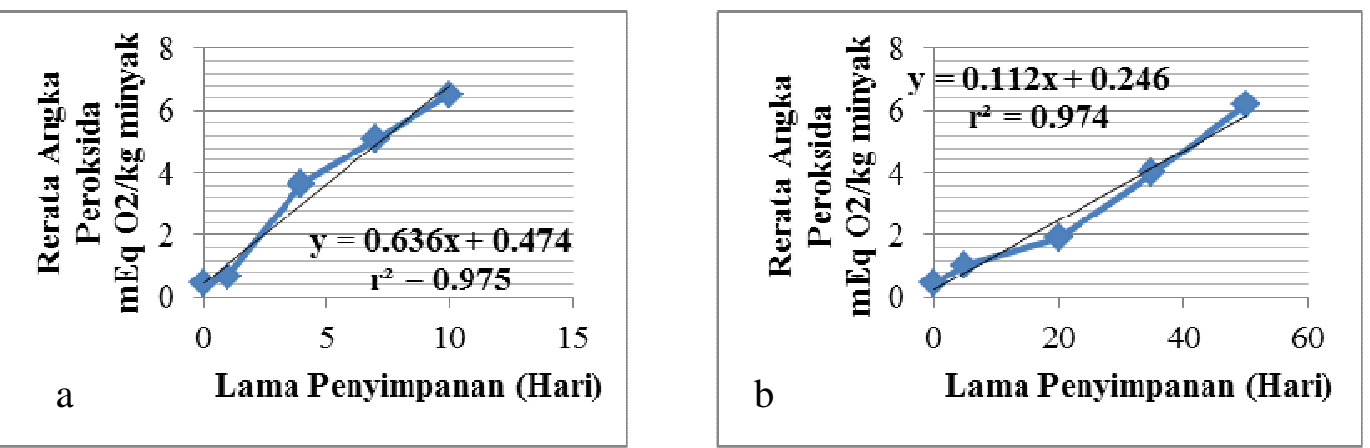

Gambar 8. Persamaan regresi pengujian angka peroksida minyak biji ketapang pada suhu penyimpanan (a) 65 ${ }^{\circ} \mathrm{C}$ dan (b) $27-30{ }^{\circ} \mathrm{C}$.

Melalui persamaan regresi juga memperlihatkan hubungan linier dengan kecenderungan naik (slope positif) pada pengujian angka peroksida sebesar 0,636 pada suhu penyimpanan $65^{\circ} \mathrm{C}$ dan 0,112 pada suhu penyimpanan 27-30 ${ }^{\circ} \mathrm{C}$. Berdasarkan nilai slope tersebut, lama penyimpanan pada suhu $65{ }^{\circ} \mathrm{C}$ lebih signifikan mempengaruhi peningkatan angka peroksida dibandingkan lama penyimpanan pada suhu $27-30{ }^{\circ} \mathrm{C}$.

Koefisien korelasi $r=0,987$ pada kedua suhu penyimpanan lebih besar dari $r$ tabel $5 \%$ dan $1 \%$, maka dapat disimpulkan bahwa lama penyimpanan pada kedua kondisi memiliki hubungan sempurna positif dan sangat signifikan terhadap peningkatan angka peroksida.

Koefisien determinasi $r^{2}=0,975$, hal ini berarti peningkatan angka peroksida 97,5\% ditentukan oleh lama penyimpanan pada suhu $65{ }^{\circ} \mathrm{C}$, sedangkan $r^{2}=0,974$, hal ini berarti peningkatan angka peroksida $97,4 \%$ ditentukan oleh lama penyimpanan pada suhu $27-30{ }^{\circ} \mathrm{C}$.

Peningkatan angka peroksida disebabkan oleh reaksi dekomposisi yang menghasilkan hidroperoksida. Hidroperoksida merupakan produk oksidasi primer yang terbentuk pada tahap reaksi penyebaran (propagasi).
Pembentukan hidroperoksida yang tidak stabil dan mudah terurai ini menyebabkan reaksi autokatalitik yang mempunyai laju peningkatan sebagai fungsi waktu dalam menghasilkan produk oksidasi sekunder seperti aldehid, keton, karbonil, dan lainlain. Angka peroksida yang rendah merupakan persyaratan minyak injeksi.

\section{Angka Penyabunan}

Angka penyabunan adalah banyaknya milligram $\mathrm{KOH}$ yang dibutuhkan untuk menyabunkan 1 gram minyak biji ketapang. Angka penyabunan dalam penelitian ini ditentukan dengan proses titrimetri.

Berdasarkan persamaan regresi pada Gambar 9 dapat dilihat bahwa semakin lama penyimpanan, minyak biji ketapang yang diujikan mempunyai kecenderungan mengalami penurunan angka penyabunan. Berdasarkan hasil penelitian sebelumnya, minyak biji ketapang memiliki angka penyabunan 68,83-207,61 mg KOH/gram minyak, sedangkan angka penyabunan awal minyak biji ketapang sebelum perlakuan, 0 hari yaitu 53,29 $\mathrm{mg}$ $\mathrm{KOH} /$ gram minyak, kemudian mengalami penurunan setelah perlakuan yaitu 18,88 mg KOH/gram pada suhu $65^{\circ} \mathrm{C}$ selama 10 hari dan $11,78 \mathrm{mg} \mathrm{KOH} /$ gram minyak pada suhu $27-30{ }^{\circ} \mathrm{C}$ selama 50 hari. 

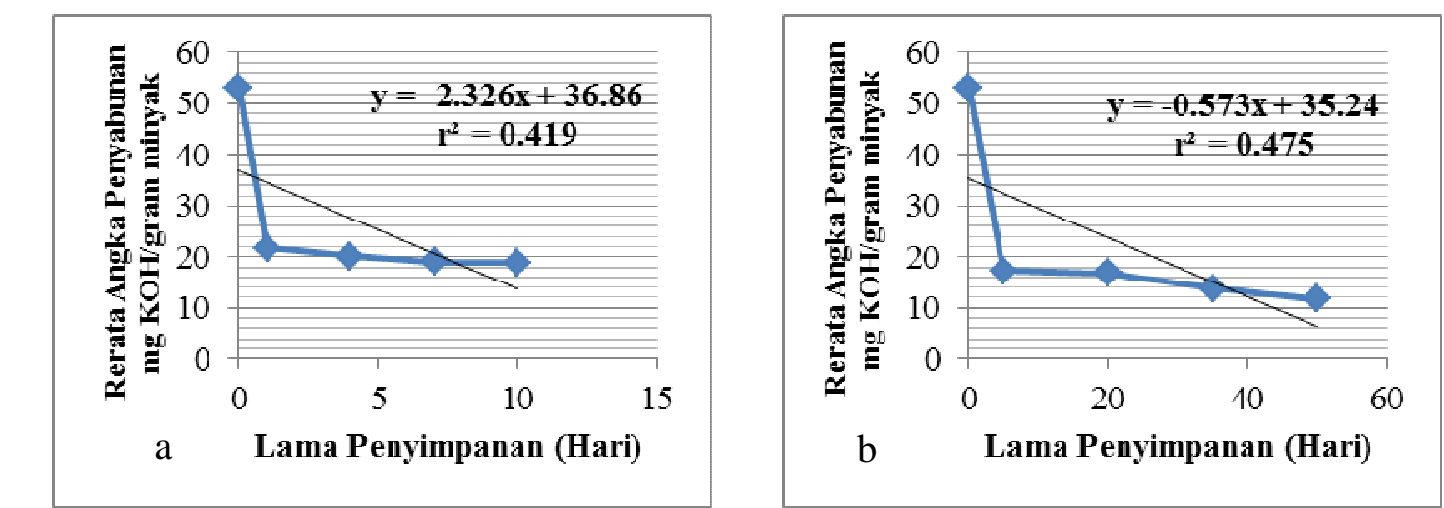

Gambar 9. Persamaan regresi pengujian angka penyabunan minyak biji ketapang pada suhu penyimpanan (a) $65^{\circ} \mathrm{C}$ dan (b) $27-30{ }^{\circ} \mathrm{C}$.

Penurunan angka penyabunan tersebut menunjukkan ketidakstabilan minyak biji ketapang selama penyimpanan, namun tidak signifikan.

Melalui persamaan regresi juga memperlihatkan hubungan linier dengan kecenderungan turun (slope negatif) pada pengujian angka penyabunan sebesar $-2,326$ pada suhu penyimpanan $65{ }^{\circ} \mathrm{C}$ dan $-0,573$ pada suhu penyimpanan $27-30{ }^{\circ} \mathrm{C}$. Berdasarkan nilai slope tersebut, lama penyimpanan pada suhu $65{ }^{\circ} \mathrm{C}$ lebih signifikan mempengaruhi penurunan angka penyabunan dibandingkan lama penyimpanan pada suhu $27-30{ }^{\circ} \mathrm{C}$.

Koefisien korelasi $r=-0,647$ pada suhu penyimpanan $65^{\circ} \mathrm{C}$ dan $-0,629$ pada suhu penyimpanan $27-30{ }^{\circ} \mathrm{C}, r$ hitung pada kedua kondisi penyimpanan tersebut lebih kecil dari $r$ tabel 5\% dan 1\%, maka dapat disimpulkan bahwa lama penyimpanan pada kedua kondisi memiliki hubungan sempurna negatif dan tidak signifikan terhadap penurunan angka penyabunan.

Koefisien determinasi $r^{2}=0,419$, hal ini berarti penurunan angka penyabunan hanya $41,9 \%$ ditentukan oleh lama penyimpanan pada suhu $65^{\circ} \mathrm{C}$, sedangkan $r^{2}=0,475$, hal ini berarti penurunan angka penyabunan hanya $47,5 \%$ ditentukan oleh lama penyimpanan pada suhu $27-30{ }^{\circ} \mathrm{C}$.

Penurunan angka penyabunan menunjukkan penurunan kualitas minyak, karena dalam transesterifikasi penggunaan katalis basa menyebabkan terjadinya reaksi penyabunan pada trigliserida minyak. Sehingga semakin rendah kandungan trigliserida minyak menyebabkan rendahnya penggunaan katalis basa pada reaksi penyabunan dan angka penyabunan semakin rendah pula. Rendahnya kandungan trigliserida minyak yang membentuk sabun disebabkan meningkatnya produksi asam lemak jenuh akibat oksidasi asam lemak tidak jenuh pada minyak. Minyak untuk injeksi memiliki persyaratan angka penyabunan yaitu 186-200 mg KOH/gram minyak.

\section{Kandungan Tokoferol}

Tokoferol merupakan antioksidan alami yang paling banyak terdapat dalam minyak nabati dan antioksidan primer yang dapat menghentikan reaksi berantai pembentukan radikal yang melepaskan hidrogen. Tokoferol mempunyai banyak ikatan rangkap yang mudah dioksidasi sehingga akan melindungi minyak dari oksidasi. 

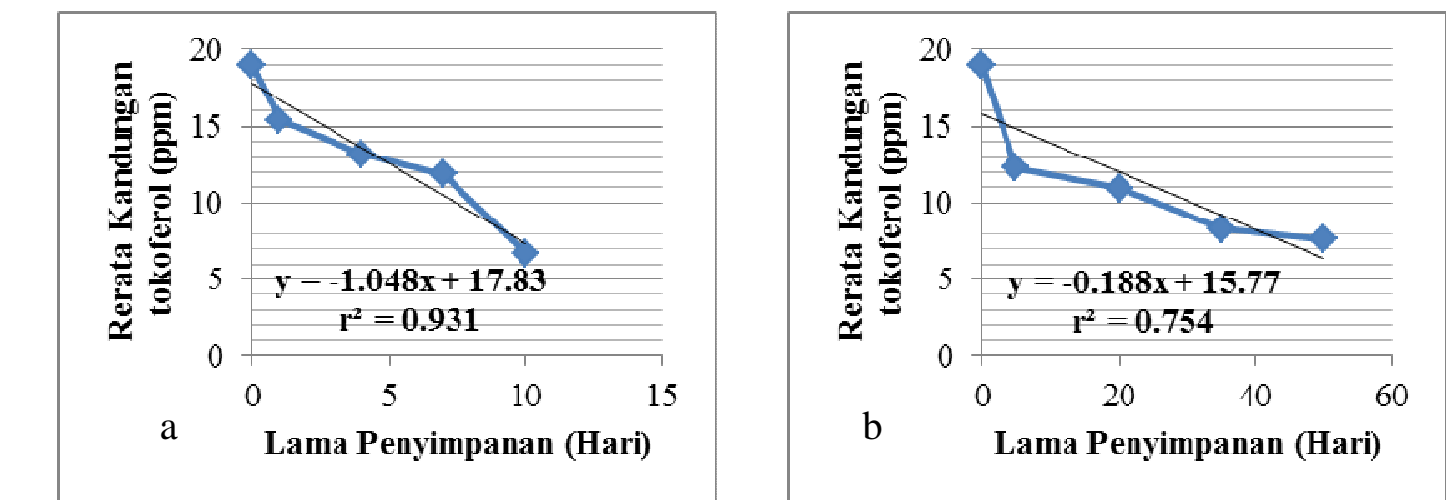

Gambar 10. Persamaan regresi pengujian kandungan tokoferol minyak biji ketapang pada suhu penyimpanan (a) $65{ }^{\circ} \mathrm{C}$ dan (b) $27-30{ }^{\circ} \mathrm{C}$.

Berdasarkan persamaan regresi pada Gambar 10 dapat dilihat bahwa semakin lama penyimpanan, minyak biji ketapang yang diujikan mempunyai kecenderungan mengalami penurunan kandungan tokoferol. Kandungan tokoferol awal minyak biji ketapang sebelum perlakuan, 0 hari yaitu 18,95 ppm, kemudian mengalami penurunan setelah perlakuan yaitu $6,73 \mathrm{ppm}$ pada suhu $65^{\circ} \mathrm{C}$ selama 10 hari dan 7,62 ppm pada suhu $27-30{ }^{\circ} \mathrm{C}$ selama 50 hari. Penurunan kandungan tokoferol tersebut menunjukkan ketidakstabilan minyak biji ketapang yang sangat signifikan selama penyimpanan.

Melalui persamaan regresi juga memperlihatkan hubungan linier dengan kecenderungan turun (slope negatif) pada kandungan tokoferol sebesar $-1,048$ pada suhu penyimpanan $65^{\circ} \mathrm{C}$ dan $-0,188$ pada suhu penyimpanan $27-30{ }^{\circ} \mathrm{C}$. Berdasarkan nilai slope tersebut, lama penyimpanan pada suhu penyimpanan $65{ }^{\circ} \mathrm{C}$ lebih signifikan mempengaruhi penurunan kandungan tokoferol dibandingkan lama penyimpanan pada suhu $27-30{ }^{\circ} \mathrm{C}$.

Koefisien korelasi $r=-0,965$ pada suhu penyimpanan $65^{\circ} \mathrm{C}$ lebih besar dari $r$ tabel $5 \%$ dan $1 \%$, maka dapat disimpulkan bahwa lama penyimpanan pada suhu penyimpanan $65{ }^{\circ} \mathrm{C}$ memiliki hubungan sempurna negatif dan sangat signifikan terhadap penurunan kandungan tokoferol. Sedangkan $r=-0,868$ pada suhu penyimpanan $27-30{ }^{\circ} \mathrm{C}$ lebih kecil dari $r$ tabel $5 \%$ dan $1 \%$, maka dapat disimpulkan bahwa lama penyimpanan pada suhu penyimpanan 27-30 ${ }^{\circ} \mathrm{C}$ memiliki hubungan sempurna negatif namun tidak signifikan terhadap penurunan kandungan tokoferol.

Koefisien determinasi $r^{2}=0,931$, hal ini berarti penurunan kandungan tokoferol 93,1\% ditentukan oleh lama penyimpanan pada suhu $65{ }^{\circ} \mathrm{C}$, sedangkan $r^{2}=0,754$, hal ini berarti penurunan kandungan tokoferol hanya $75,4 \%$ ditentukan oleh lama penyimpanan pada suhu $27-30{ }^{\circ} \mathrm{C}$.

Penurunan kandungan tokoferol selama penyimpanan mengindikasikan peningkatan radikal bebas yang terbentuk pada reaksi autooksidasi minyak biji ketapang yang mengandung asam lemak tidak jenuh. Radikal ini bereaksi secara cepat dengan oksigen udara menghasilkan radikal peroksi, yang dapat menghasilkan hidroperoksida dan radikal bebas baru yang dapat bereaksi dengan asam lemak tidak jenuh yang lain (tahap propagasi) sehingga menyebabkan peningkatan pembentukan produk oksidasi primer dan sekunder. Tokoferol yang berperan dalam 
pencegahan oksidasi asam lemak akan kehilangan ikatan rangkapnya sehingga menurunkan kandungannya dalam minyak.

\section{KESIMPULAN}

Hasil analisis pada parameter bau, rasa, $\mathrm{pH}$, bobot jenis, angka penyabunan, dan kandungan tokoferol menunjukkan hubungan linier dengan kecenderungan turun, pengujian terhadap parameter viskositas, angka asam, dan angka peroksida menunjukkan hubungan linier dengan kecenderungan naik, sedangkan parameter warna minyak biji ketapang cenderung stabil selama penyimpanan pada suhu ruang maupun suhu ekstrim. Lama penyimpanan pada suhu ekstrim lebih signifikan mempengaruhi hasil pengujian pada parameter fisik dan kimia minyak biji ketapang dibandingkan pada suhu ruang.

\section{UCAPAN TERIMA KASIH}

Seluruh staf laboran di Fakultas Farmasi dan sahabat-sahabat terbaik penulis yang selalu memberikan dukungan dan bantuan selama penyelesaian penelitian ini.

\section{DAFTAR PUSTAKA}

1. Agatemor, C.; \& Ukhun, M.E. 2006. Nutritional Potential of The Nut of Tropical
Almond (Terminalia catappa L.). Pakistan Journal Of Nutrition 5: Pakistan.

2. Agoes, G. 2009. Sediaan Farmasi Steril. Penerbit ITB: Bandung.

3. AOAC. 1990. Official Methods of Analysys. Association of Official Analytical Chemists $15^{\text {th }}$ Ed: Washington DC.

4. Balogun, A. M.; \& Fetuga, B. L. 1985. Fatty Acid Composition of Seed Oils of Some Membes of The Meliaceae and Combretaceae Families. Journal of American Oil Chemist Society, Vol. 62, No. 3.

5. Departemen Kesehatan RI. 1979. Farmakope Indonesia Edisi Ketiga. Departemen Kesehatan RI: Jakarta.

6. Harborne, J. B. 2006. Metode Fitokimia. Penerbit ITB: Bandung.

7. Handayani, M. P.; \& Wahyuono, S. 2008. Analisis Biji Ketapang (Terminalia catappa L.) sebagai Suatu Alternatif Sumber Minyak Nabati. Fakultas Farmasi Universitas Gadjah Mada: Yogyakarta.

8. Nurhadi, S. C. 2012. Pembuatan Sabun Mandi Gel Alami dengan Bahan Aktif Mikroalga Chlorella pyrenoidosa Beyerinck dan Minyak Atsiri Lavandula latifolia Chaix. Program Studi Teknik Industri Fakultas Sains dan Teknologi Universitas Ma Chung: Malang.

9. Schmitt, W. H. 1996. Skin Care Products, Blackie Academe and Professional: London.

10. Suwarso, W.P.; Gani, I.Y.; \& Kusyanto. 2007. Sintesis Biodiesel dari Minyak Biji Ketapang (Terminalia catappa Linn.) yang Berasal dari Tumbuhan di Kampus UI Depok. Laboratorium Kimia Organik-Departemen Kimia Fakultas Matematika dan Ilmu Pengetahuan Alam-Universitas Indonesia: Depok.

11. Winarno, F. G. 1984. Kimia Pangan dan Gizi. PT Gramedia Pustaka Utama: Jakarta. 